\title{
Penerapan Metode Mind Mapping untuk Meningkatkan Keterampilan Berbicara (Berceramah) Siswa SMK
}

\author{
Mustakim $^{1^{*}}$ \\ ${ }^{1}$ Jurusan Pendidikan Bahasa dan Sastra Indonesia, Universitas Pendidikan Ganesha, Singaraja, Indonesia
}

\section{ART I CLE INF O}

Article history:

Received March 16, 2021

Revised March 25, 2021

Accepted August 20, 2021

Available online November 25, 2021

Kata Kunci

Metode Mind Mapping,

Keterampilan Berbicara

Keywords:

Mind Mapping Method, Speaking Skills

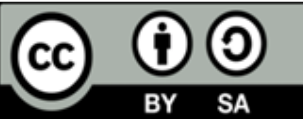

This is an open access article under the CC BY-SA license.

Copyright $(2021$ by Author. Published by Universitas Pendidikan Ganesha.

\begin{abstract}
A B S T R A K
Berbicara merupakan salah satu keterampilan dasar yang harus dimiliki oleh seseorang agar dapat berkomunikasi dengan individu lainnya. Hanya saja tidak semua orang mampu berbicara dengan baik, khususnya berbicara di depan umum. Tujuan dari penelitian ini adalah untuk mendeskripsikan peningkatan keterampilan berbicara dalam pembelajaran berceramah pada siswa SMK dengan menerapkan metode mind mapping. Penelitian ini tergolong ke dalam penelitian tindakan kelas yang dilaksanakan dalam dua siklus penelitian. Subjek yang terlibat dalam penelitian ini yakni 32 orang siswa SMK. Pengumpulan data dalam penelitian dilakukan dengan menggunakan metode observasi, tes, angket, dan wawancara. Instrumen yang digunakan yakni tes kemampuan berbicara serta lembar observasi. Data hasil penelitian dianalisis menggunakan teknik deskriptif kualitatif dan teknik analisis deskriptif kuantitatif. Hasil penelitian menunjukkan bahwa pada siklus I rata-rata kemampuan berbicara siswa yakni 77,3 yang berada pada kategori baik dan meningkat menjadi 86,5 pada siklus II. Secara klasikal meningkat dari $50 \%$ pada siklus I menjadi $84,3 \%$ pada siklus II. Selain itu, penerapan metode mind mapping juga mendapatkan respons yang positif. Hal ini ditunjukkan pada data respons siklus I dengan skor 19,03 \% dengan kategori positif dan meningkat menjadi 20,8 \% kategori positif pada siklus II. Berdasarkan data hasil penelitian tindakan kelas tersebut, maka penerapan metode mind mapping dapat meningkatkan keterampilan berbicara siswa secara efektif.
\end{abstract}

\section{A BS TRACT}

Speaking is one of the basic skills that a person must possess to communicate with other individuals. It is just that not everyone can speak well, especially speaking in public. This study aimed to describe the improvement of speaking skills in teaching lectures to vocational students by applying the mind mapping method. This research is included in classroom action research carried out in two research cycles. The subjects involved in this study were 32 SMK students. Data collection in the study was carried out using the methods of observation, tests, questionnaires, and interviews. The instruments used were speaking ability tests and observation sheets. The research data were analyzed using qualitative and quantitative descriptive techniques. The results showed that in the first cycle, the students' average speaking ability was 77.3, which was in the excellent category, and increased to 86.5 in the second cycle. Moreover, it classically increased from 50\% in the first cycle to $84.3 \%$ in the second cycle. In addition, the application of the Mind Mapping method also received a positive response. It is shown in the response data in the first cycle with a score of $19.03 \%$ with a positive category which increased by $20.8 \%$ in the positive category in the second cycle. Based on the data from the classroom action research, the application of the Mind Mapping method can improve students' speaking skills effectively.

\section{PENDAHULUAN}

Berkomunikasi merupakan salah satu kegiatan yang tidak bisa dilepaskan dari kehidupan manusia (Hariko, 2017). Sebagai makhluk sosial, manusia harus berkomunikasi dengan manusia lain guna memenuhi kebutuhan hidupnya. Seseorang yang mempunyai kemampuan berbicara atau berkomunikasi yang baik akan lebih mudah bergaul dalam lingkungan masyarakat (Pebriana, 2017; Sumaryanti, 2017). 
Keterampilan berbicara mempunyai hubungan yang erat dengan proses-proses berpikir, sehingga untuk mampu berbicara dengan baik seseorang harus rajin latihan yang praktik langsung (Firmansyah, 2017; Rezeki et al., 2019). Dalam pembelajaran Bahasa Indonesia di berbagai jenjang pendidikan, aspek berbicara menjadi salah satu aspek yang paling ditekankan. Hal ini dikarenakan melalui keterampilan berbicara siswa akan lebih mudah memahami materi pembelajaran yang disampaikan oleh gurunya (Aprinawati, 2017). Pada dasarnya keterampilan berbicara dapat mendasari siswa aktif dalam mengikuti semua proses pembelajaran (Liniswarti, 2021; Priatna \& Setyarini, 2019). Keterampilan berbicara merupakan keterampilan yang mekanistik (Wijayanti, 2020). Semakin banyak berlatih, semakin dikuasai dan terampil seseorang dalam berbicara (Darmuki \& Hariyadi, 2019). Tidak ada orang yang langsung terampil berbicara tanpa melalui proses latihan (Karyadi, 2018). Terdapat berbagai materi berbicara yang dapat dibelajarkan kepada siswa. Salah satu materi berbicara yang disajikan dalam pembelajaran Bahasa Indonesia jenjang SMA yakni materi ceramah. Ceramah atau yang banyak juga menyebutnya dengan pidato adalah kegiatan berbicara di muka umum untuk menyampaikan suatu informasi dengan tujuan memberikan nasihat dan petunjuk tentang sesuatu hal yang bersifat aktual (Putri et al., 2017; Riyanto, 2020; Satriyo, 2021). Melalui kegiatan berbicara, seseorang akan dapat mengungkapkan pikiran, gagasan, ide, dan pendapat serta menyampaikan informasi tentang suatu peristiwa (Aprinawati, 2017; Hermansyah et al., 2017).

Hanya saja kenyataan di lapangan menunjukkan bahwa tidak semua siswa mampu berbicara dengan baik (A. Hidayati, 2018; Tambuna, 2018). Masih terdapat banyak siswa yang malu serta tidak percaya untuk berbicara di depan orang banyak (Ekaningtyas, 2018; Kartikawati, 2020). Hal ini sejalan dengan hasil observasi yang telah dilakukan di SMK Negeri 1 Singaraja. Hasil observasi menunjukkan bahwa kemampuan siswa kelas XI B AKL dalam keterampilan berbicara masih berada dalam kategori cukup, sehingga perlu untuk ditingkatkan, terutama dalam hal mengemukakan pendapat atau mengemukakan argumen. Kurangnya kemampuan siswa dalam berbicara kemudian berdampak pada rendahnya hasil belajar siswa. Hasil belajar siswa masih berada di bawah kriteria ketuntasan minimal (KKM) yaitu 70,00, yang seharusnya mencapai nilai standar ketuntasan minimal sebesar 78,00. Saat proses pembelajaran berlangsung, sebagian siswa lebih banyak memilih berdiam diri daripada berbicara, biarpun itu saat diberikan pertanyaan oleh guru. Adakalanya juga, siswa bermain-main ataupun mengobrol saat pelajaran berlangsung dan ada pula yang mengantuk. Permasalahan-permasalahan dalam hal seperti ini jika dibiarkan secara terus menerus akan berdampak pada penurunan keterampilan siswa dalam aspek berbahasa lainnya.

Salah satu upaya yang dapat dilakukan untuk meningkatkan kemampuan berbahasa siswa, yakni dengan menerapkan metode pembelajaran mind mapping. Metode Mind Mapping atau yang biasa disebut dengan teknik peta konsep merupakan salah satu teknik yang dapat digunakan dalam keterampilan berbicara siswa. Peta konsep merupakan cara kreatif siswa secara individual untuk menghasilkan ide-ide, mencatat pelajaran, atau merencanakan penelitian baru (Afriyanti, 2020; Supadmi et al., 2017; Warahmah et al., 2020). Metode peta konsep mencerminkan cara kerja alami otak (Saharah \& Indihadi, 2019). Peserta didik mampu mengolah gagasan dengan peta konsep kemudian merencanakan bagaimana menyampaikannya (Aprinawati, 2017). Melalui teknik peta konsep daftar informasi yang panjang bisa dialihkan menjadi diagram warna-warni, sangat teratur, dan mudah diingat yang bekerja selaras dengan cara kerja alami otak dalam melakukan berbagai hal (Sarumaha, 2019). Penggunaan metode mind mapping akan memudahkan siswa untuk merancang materi berbicara dan mengembangkan kata-kata dari ide-ide pokok yang telah dirancang (Darmuki, 2020).

Beberapa penelitian yang telah dilakukan sebelumnya menunjukkan bahwa strategi pembelajaran mind mapping lebih efektif dibandingkan dengan strategi pembelajaran konvensional, dan adanya hubungan interaksi antara strategi pembelajaran mind mapping dan rasa percaya diri terhadap kemampuan berbicara siswa (Maria et al., 2021). Hasil penelitian lainnya juga mengungkapkan bahwa mind map yang diterapkan secara signifikan dapat meningkatkan minat dan hasil belajar keterampilan berbicara mahasiswa (Darmuki, 2020). Hal serupa juga diungkapkan oleh penelitian ketiga yakni penerapan metode mind map berbasis drill dapat meningkatkan keaktifan dan hasil belajar kemampuan berbicara mahasiswa (Hidayati, 2020). Berdasarkan beberapa hasil penelitian tersebut dapat dikatakan bahwa metode mind mapping sangat efektif digunakan untuk meningkatkan kemampuan berbicara siswa maupun mahasiswa. Hanya saja pada penelitian sebelumnya belum terdapat kajian mengenai penerapan penggunaan metode mind mapping untuk meningkatkan kemampuan berceramah siswa SMK. Sehingga penelitian ini difokuskan pada kajian tersebut dengan tujuan untuk mendeskripsikan peningkatan keterampilan berbicara dalam pembelajaran berceramah pada siswa kelas XI B AKL SMK Negeri 1 Singaraja dengan menerapkan metode mind mapping. 


\section{METODE}

Penelitian ini merupakan jenis penelitian tindakan kelas (PTK). Penelitian tindakan kelas merupakan penelitian yang dilakukan untuk memecahkan permasalahan yang dihadapi oleh guru dan siswa ketika proses belajar-mengajar di kelas berlangsung. Disebut penelitian tindakan kelas (PTK) karena jenis penelitian ini menawarkan suatu cara dan prosesdur untuk memperbaiki dan meningkatkan kualitas belajar-mengajar di kelas. Penelitian tindakan kelas dilaksanakan dalam dua siklus penelitian yakni siklus I dan siklus II. Pada tiap-tiap siklus penelitian terdapat empat tahapan penelitian yang terdiri atas perencanaan, tindakan, pengamatan, dan refleksi. Subjek yang terlibat dalam penelitian ini yakni siswa kelas XI B AKL SMK Negeri 1 Singaraja, yang berjumlah 32 orang. Pengumpulan data dalam penelitian dilakukan dengan menggunakan metode wawancara, tes, dan angket. Instrumen yang digunakan yakni tes kemampuan berbicara siswa dengan menerapkan metode mind mapping, lembar observasi berupa langkah-langkah pembelajaran dengan menerapkan metode mind mapping, serta lembar quesioner berupa respon siswa terhadap keterampilan bercerita dengan menerapkan metode mind mapping. Data yang diperoleh dari hasil penelitian kemudian dianalisis dengan teknik analisis deskriptif kualitatif dan deskriptif kuantitatif. Kriteria keberhasilan pelaksanaan siklus dapat ditunjukkan dengan perolehan persentase sebanyak $75 \%$ dari keseluruhan siswa yang merespons positif terhadap tindak pembelajaran. Kriteria ditentukan dengan KKM yang sudah dirancang oleh pihak sekolah. Jika tindakan yang dilakukan sudah mencapai kriteria keberhasilan, penelitian dapat dihentikan. Siklus tindakan yang mampu mencapai kriteria keberhasilan sekaligus dianggap sebagai tindakan yang terbaik yang memenuhi kriteria keberhasilan.

\section{HASIL DAN PEMBAHASAN}

Hasil

Penelitian tindakan kelas ini diawali dengan pelaksanaan siklus I. Pelaksanaan siklus I didasarkan pada hasil observasi awal yang menunjukkan bahwa kemampuan berbicara siswa masih berada di bawah KKM. Siklus I dilaksanakan dalam tiga kali pertemuan. Hasil yang diperoleh pada siklus I menunjukkan bahwa siswa yang tuntas pada siklus I hanya enam belas orang siswa (50\%) dengan nilai rata-rata sebesar 77,3. Hasil yang diperoleh pada siklus I belum dapat memenuhi kriteria ketuntasan, sehingga harus dilanjutkan pada pelaksanaan siklus II. Selain dilaksanakan penilaian terhadap hasil belajar siswa dalam proses berbicara pada siklus I juga dilaksanakan analisis terhadap respon siswa. Hasil analisis menunjukkan bahwa berdasarkan kriteria penilaian terhadap respons siswa, dari 32 orang siswa, memberikan respons positif. Jika dilihat dari hasil kuesioner respons siswa, tidak ada siswa yang memberikan respon negatif. Dapat dikatakan bahwa penerapan metode mind mapping untuk meningkatkan keterampilan berbicara khususnya berceramah telah mendapatkan respons positif.

Siklus II pada penelitian ini dilakukan dengan rencana yang lebih matang dan berupaya untuk memperbaiki berbagai permasalahan yang muncul pada siklus I. Adanya perbaikan-perbaikan pembelajaran yang mengarah pada peningkatan hasil belajar. Hasil pembelajaran baik yang berupa proses maupun hasil tes keterampilan berbicara (berceramah) siswa dapat meningkat dibandingkan pada siklus I. Siklus II dilaksanakan satu pertemuan. Akan tetapi, di akhir pertemuan nanti siswa diminta untuk membuat hasil ceramah mereka dalam bentuk video. Hasil yang diperoleh dari pelaksanaan siklus II menunjukkan bahwa dari 32 hanya terdapat 5 orang siswa yang nilainya tidak tuntas dan 27 orang lainnya sudah memiliki nilai diatas KKM dengan nilai rata-rata mencapai 86,5. Hasil analisis respon siswa pada siklus II juga menunjukkan hasil bahwa dari 32 orang siswa yang mengisi angket, 5 orang siswa dari jumlah siswa yang memberikan respons sangat positif terhadap penerapan metode mind mapping. Sisanya, 17 orang siswa dari jumlah siswa memberikan respons positif. Jadi, dapat disimpulkan bahwa penerapan metode mind mapping untuk meningkatkan keterampilan berbicara (berceramah) di kelas XI B AKL SMK Negeri 1 Singaraja dikatakan berhasil karena dari 32 jumlah siswa, semuanya memberikan respons positif. Selanjutnya, berdasarkan hasil observasi dari observer, pelaksanaan pembelajaran telah dilakukan oleh guru dengan sistematis dan semua langkah pembelajaran telah dilakukan. Selain itu, tidak ditemukan hal-hal yang perlu diperbaiki pada saat pelaksanaan pembelajaran. Sehingga dapat dinyatakan bahwa penelitian telah berhasil dilaksanakan dan penelitian dapat dicukupkan sampai pada pelaksanaan siklus II.

\section{Pembahasan}

Hasil yang diperoleh pada penelitian ini menunjukkan bahwa terdapat peningkatan kemampuan berbicara siswa pada setiap siklusnya. Adanya peningkatan kemampuan siswa pada tiap siklus penelitian tidak terlepas dari penggunaan model pembelajaran mind mapping. Mind mapping atau peta pikiran merupakan salah satu metode pembelajaran yang dilakukan melalui proses pemetaan ide-ide pokok atau 
konsep pikiran ke dalam cabang-cabang pemetaan yang kemudian membentuk hubungan yang saling berkaitan (Aprinawati, 2018; Armariena, 2020; Setyarini, 2019; Wulandari et al., 2019). Penggunaan mind mapping dalam proses pembelajaran akan dapat membantu siswa untuk menyusun sebuah ide atau gagasan secara menyeluruh tentang poko-pokok permasalahan yang akan dibahas (Masita \& Wulandari, 2018; Sulfemi, 2019). Melalui mind mapping siswa akan dapat mengetahui pola berpikir yang sistematis dan terstruktur (Saharah \& Indihadi, 2019).

Metode pembelajaran mind mapping sangat cocok digunakan dalam meningkatkan kemampuan berbicara siswa. Melalui mind mapping, siswa akan mengetahui pokok-pokok pembicaraan yang akan dibahas serta akan mengetahui alur materi ceramah yang akan dibawakan (Subakti \& Handayani, 2020). Berbicara menjadi salah satu keterampilan berbahasa yang harus dimiliki oleh setiap individu (Husada et al., 2019; Priatna \& Setyarini, 2019). Melalui proses berbicara, seseorang akan dapat berkomunikasi dengan manusia lainnya guna memenuhi kebutuhan hidupnya (Noermanzah, 2019). Dalam bidang pendidikan kemampuan berbicara menjadi salah satu keterampilan yang harus dikuasai setiap siswa, hal ini dikarenakan melalui proses berbicara kegiatan pembelajaran akan dapat berlangsung secara dua arah dan proses pembelajaran akan lebih bermakna. Terdapat berbagai macam keterampilan berbicara yang dibelajarkan kepada siswa, salah satunya adalah keterampilan berceramah. Ceramah merupakan kegiatan berbicara dimuka umum untuk menyampaikan suatu informasi dengan tujuan memberikan nasihat dan petunjuk tentang sesuatu hal yang bersifat actual (Putri et al., 2017; Riyanto, 2020; Satriyo, 2021). Seseorang akan dianggap mampu memberikan ceramah atau berbicara dengan baik apabila mampu menggunakan bahasa yang baik dan benar serta mampu menyampaikan isi materi dengan lugas dan mudah dipahami.

Hasil yang diperoleh pada penelitian ini sejalan dengan beberapa penelitian sebelumnya yang juga mengungkapkan bahwa strategi pembelajaran Mind Mapping lebih efektif dibandingkan dengan strategi pembelajaran konvensionalm dan adanya hubungan interaksi antara strategi pembelajaran mind mapping dan rasa percaya diri terhadap kemampuan berbicara siswa (Maria et al., 2021). Hasil penelitian lainnya juga mengungkapkan bahwa mind map yang diterapkan secara signifikan dapat meningkatkan minat dan hasil belajar keterampilan berbicara mahasiswa (Darmuki, 2020). Hal serupa juga diungkapkan oleh penelitian ketiga yakni penerapan metode mind map berbasis drill dapat meningkatkan keaktifan dan hasil belajar kemampuan berbicara mahasiswa (N. A. Hidayati, 2020). Berdasarkan hasil penelitian yang didukung oleh hasil penelitian terdahulu dapat diketahui bahwa penggunaan metode mind mapping secara signifikan dapat meningkatkan kemampuan berbicara seseorang.

\section{SIMPULAN}

Penggunaan metode pembelajaran mind mapping, secara signifikan dapat meningkatkan kemampuan berbicara (berceramah) siswa SMK. Selain mampu meningkatkan kemampuan berbicara, penggunaan metode mind mapping juga mendapatkan respon yang positif dari siswa, sehingga mampu meningkatkan aktivitas belajarnya.

\section{DAFTAR RUJUKAN}

Afriyanti, N. (2020). Upaya Meningkatkan Kemampuan Peserta Didik Menulis Teks Descriptive Mata Pelajaran Bahasa Inggris Menggunakan Model Mind Mapping. Jurnal Tunas Pendidikan, 2(2), 3245. https://doi.org/10.52060/pgsd.v2i2.244.

Aprinawati, I. (2017). Penggunaan Media Gambar Seri untuk Meningkatkan Kemampuan Berbicara Anak Usia Dini. Jurnal Obsesi: Jurnal Pendidikan Anak Usia Dini, 1(1), 72. https://doi.org/10.31004/obsesi.v1i1.33.

Aprinawati, I. (2018). Penggunaan Model Peta Pikiran (Mind Mapping) untuk Meningkatkan Pemahaman Membaca Wacana Siswa Sekolah Dasar. Jurnal Basicedu, 2(1), 140-147. https://doi.org/10.31004/basicedu.v2i1.35.

Armariena, D. N. (2020). Penulisan Makalah Mahasiswa pada MKU Bahasa Indonesia dengan Metode Mind Mapping. Wahana Didaktika: Jurnal Ilmu Kependidikan, 17(2), 258. https://doi.org/10.31851/wahanadidaktika.v17i2.4147.

Darmuki, A. (2020). Peningkatan Minat dan Hasil Belajar Keterampilan Berbicara Menggunakan Metode Mind Map pada Mahasiswa Kelas IA PBSI IKIP PGRI Bojonegoro Tahun Akademik 2019/2020. Kredo: Jurnal Ilmiah Bahasa Dan Sastra, 3(2), 263-276. https://doi.org/10.24176/kredo.v3i2.4687.

Darmuki, A., \& Hariyadi, A. (2019). Peningkatan Keterampilan Berbicara Menggunakan Metode Kooperatif Tipe Jigsaw pada Mahasiswa PBSI Tingkat I-B IKIP PGRI Bojonegoro Tahun Akademik 2018/2019. 
Kredo: Jurnal Ilmiah Bahasa dan Sastra, 2(2), 256-267. https://doi.org/10.24176/kredo.v2i2.3343.

Ekaningtyas, D. P. (2018). Peningkatan Keterampilan Berbicara Menggunakan Metode Sosiodrama. Paedagogie, 13(2), 71-76. https://doi.org/10.31603/paedagogie.v13i2.2368.

Firmansyah, M. B. (2017). Model Pembelajaran Diskusi Berbasis Perilaku Berliterasi untuk Keterampilan Berbicara. Jurnal Ilmiah Edukasi \& Sosial, 8(2), 119-125. http://jiesjournal.com/index.php/jies/article/ download/96/86.

Hariko, R. (2017). Landasan Filosofis Keterampilan Komunikasi Konseling. Jurnal Kajian Bimbingan dan Konseling, 2(2), 41-49. https://doi.org/10.17977/um001v2i22017p041.

Hermansyah, A. K., Suyono, S., \& Hasanah, M. (2017). Desain Pembelajaran Berbicara untuk Mengenalkan Nilai-Nilai Moral Kemanusiaan melalui Bermain Peran. Jurnal Edukasi, 4(1), 38. https://doi.org/10.19184/jukasi.v4i1.5089.

Hidayati, A. (2018). Peningkatan Keterampilan Berbicara melalui Pendekatan Komunikatif Kelas V SD Padurenan II di Bekasi Tahun Pelajaran 2016/2017. Jurnal Ilmiah Pendidikan Dasar, 5(2), 83. https://doi.org/10.30659/pendas.5.2.83-95.

Hidayati, N. A. (2020). Penerapan Metode Mind Map Berbasis Drill untuk Meningkatkan Kemampuan Berbicara Mahasiswa di Prodi PBSI IKIP PGRI Bojonegoro. Jurnal Educatio FKIP UNMA, 6(2), 462468. https://doi.org/10.31949/educatio.v6i2.578.

Husada, A., Untari, M. F. A., \& Tsalatsa, A. N. (2019). Peningkatan Keterampilan Berbicara dengan Metode Bermain Peran pada Siswa. Journal of Education Action Research, 3(2), 124. https://doi.org/10.23887/jear.v3i2.17268.

Kartikawati, D. (2020). Pelatihan Pidato untuk Meningkatkan Kepercayaan Diri Siswa Sekolah Dasar di Jakarta. Dinamisia: Jurnal Pengabdian kepada Masyarakat, 4(1). https://doi.org/10.31849/dinamisia.v4i1.3695.

Karyadi, A. C. (2018). Peningkatan Keterampilan Berbicara melalui Metode Storytelling Menggunakan Media Big Book. Jurnal Pengabdian Masyarakat (JPM-IKP), 1(02). https://doi.org/10.31326/jmpikp.v1i02.70.

Liniswarti, L. L. (2021). Meningkatkan Keterampilan Berbicara Siswa Belajar Bahasa Inggris melalui Penggunaan Media Pembelajaran Invitation pada Siswa Kelas VIII A SMP Negeri 3 Muara Bungo. Jurnal Tunas Pendidikan, 4(1), 22-32. https://doi.org/10.52060/pgsd.v4i1.569.

Maria, Y., Kara, D. K., \& Liru, M. W. (2021). Pengaruh Strategi Pembelajaran Mind Mapping dan Rasa Percaya Diri terhadap Kemampuan Berbicara Bahasa Inggris. Edukatif: Jurnal Ilmu Pendidikan, 3(6), 4980-4986. https://doi.org/10.31004/edukatif.v3i6.1600.

Masita, M., \& Wulandari, D. (2018). Pengembangan Buku Saku Berbasis Mind Mapping pada Pembelajaran IPA. Jurnal Kreatif: Jurnal Kependidikan Dasar, 9(1), 75-82. https://doi.org/10.15294/kreatif.v9i1.16509.

Noermanzah. (2019). Bahasa sebagai Alat Komunikasi, Citra Pikiran, dan Kepribadian. Prosiding Seminar $\begin{array}{llll}\text { Nasional Bulan } & \text { Bahasa 306-319. }\end{array}$ https://ejournal.unib.ac.id/index.php/semiba/article/view/ 11151.

Pebriana, P. H. (2017). Analisis Kemampuan Berbahasa dan Penanaman Moral pada Anak Usia Dini melalui Metode Mendongeng. Jurnal Obsesi : Jurnal Pendidikan Anak Usia Dini, 1(2), 139. https://doi.org/10.31004/obsesi.v1i2.34.

Priatna, A., \& Setyarini, G. (2019). Pengaruh Model Pembelajaran Role Playing terhadap Keterampilan Berbicara Siswa Kelas IV SD pada Pembelajaran Bahasa Indonesia. Pendas: Jurnal Ilmiah Pendidikan Dasar, 4(2). https://doi.org/10.23969/jp.v4i2.2139.

Putri, H. N., Sunarti, I., \& Samhati, S. (2017). Kemampuan Berpidato Siswa Kelas X SMA Negeri 3 Kotabumi dan Implikasinya. Jurnal Kata (Bahasa, Sastra, dan Pembelajarannya), 5(4), 1-23. http://jurnal.fkip.unila.ac.id/index.php/BIND01/article/view/14509/10576.

Rezeki, N., Syahrial, \& Surya, Y. F. (2019). Peningkatan Keterampilan Berbicara dengan Menggunakan Model Kooperatif Think Pair Share. Jurnal Pendidikan Tambusai, 3(5), 946-954. https://doi.org/10.31004/jptam.v3i3.301.

Riyanto, A. (2020). Penggunaan Video Sebagai Media Tutorial Pembelajaran terhadap Kemampuan Berceramah Siswa. Jurnal KIBASP (Kajian Bahasa, Sastra Dan Pengajaran), 3(2). https://doi.org/10.31539/kibasp.v3i2.1111.

Saharah, S., \& Indihadi, D. (2019). Penggunaan Teknik Mind Mapping pada Keterampilan Menulis Ringkasan Siswa dalam Pembelajaran Bahasa Indonesia. Jurnal Ilmiah Pendidikan Guru Sekolah Dasar, 6(1), 9-15. http://ejournal.upi.edu/index.php/pedadidaktika/index.

Sarumaha, F. (2019). Penerapan Model Mind Mapping (Peta Pikiran) terhadap Keterampilan Menulis Teks Eksposisi Siswa Kelas X IPS SMA Kristen Hosana Medan 2018/2019. Asas: Jurnal Sastra, 8(2). 
https://doi.org/10.24114/ajs.v8i2.15441.

Satriyo, E. (2021). Penerapan Pendekatan Komunikatif dalam Proses Pembelajaran Keterampilan Berbicara untuk Meningkatkan Kemampuan Berpidato Siswa Kelas IX. JURNAL ABIWARA, 2(5). http://www.e-jurnalnasional.com/index.php/abiwarajurnal/article/view/37/18.

Setyarini, D. (2019). Metode Pembelajaran Mind Map untuk Meningkatkan Prestasi Belajar Anak Didik Sekolah Dasar. Jurnal Ilmiah Pendidikan Dasar, 6(1), 30. https://doi.org/10.30659/pendas.6.1.3044.

Subakti, H., \& Handayani, E. S. (2020). Pengembangan Menulis Cerita Pendek Kearifan Lokal Menggunakan Model Mind Mapping Siswa SD Kota Samarinda. Jurnal Serambi Ilmu, 21(2), 171-184. https://doi.org/10.32672/si.v21i2.1941.

Sulfemi, W. B. (2019). Model Pembelajaran Kooperatif Mind Mapping Berbantu Audio Visual dalam Meningkatkan Minat, Motivasi, dan Hasil Belajar IPS. Jurnal PIPSI (Jurnal Pendidikan IPS Indonesia), 4(1), 13. https://doi.org/10.26737/jpipsi.v4i1.1204.

Sumaryanti, L. (2017). Peran Lingkungan terhadap Perkembangan Bahasa Anak. Jurnal Studi Kependidikan, 7(1). https://doi.org/10.24269/muaddib.v7i01.552.

Supadmi, N. L., Wiratma, I. G. L., \& Merta, L. M. (2017). Penerapan Metode Mind Mapping untuk Meningkatkan Aktivitas dan Hasil Belajar Kimia Siswa Kelas X MIA. Jurnal Pendidikan Kimia Indonesia, 1(2), 48. https://doi.org/10.23887/jpk.v1i2.12811.

Tambuna, P. (2018). Pembelajaran Keterampilan Berbicara di Sekolah Dasar. Jurnal Ilmiah, 2(1). https://doi.org/10.36764/jc.v2i1.109.

Warahmah, M., Mawardi, \& Nurasiah. (2020). Pengaruh Metode Pembelajaran Inkuiri dengan Model Mind Mapping (Peta Pikiran) terhadap Prestasi Belajar Siswa Kelas VII SMP Negeri 13 Banda Aceh. Jurnal Ilmiah Mahasiswa Pendidikan Sejarah, 5(1), 67-76. https://doi.org/10.24815/jimps.v5i1.15083.

Wijayanti, A. Y. (2020). Kuliah Keterampilan Berbahasa SD dengan Metode Role Playing pada Mahasiswa Semester V Program Studi PGSD Undaris Ungaran. Jurnalwawasan Pengembangan Pendidikan, 8(2). https://ejournal.undaris.ac.id/index.php/waspada/article/view/171/128.

Wulandari, F. A., Mawardi, M., \& Wardani, K. W. (2019). Peningkatan Keterampilan Berpikir Kreatif Siswa Kelas 5 Menggunakan Model Mind Mapping. Jurnal Ilmiah Sekolah Dasar, 3(1), 10. https://doi.org/10.23887/jisd.v3i1.17174. 